\title{
Kesiapan menikah mahasiswa ditinjau dari jenis kelamin, latar belakang budaya dan sosial ekonomi
}

\author{
Lisa Putriani $^{\left.{ }^{*}\right)}$, Daharnis Daharnis ${ }^{2}$, Riska Ahmad ${ }^{3}$ \\ ${ }^{123}$ Universitas Negeri Padang \\ *Corresponding author, e-mail: lisaputriani@konselor.org
}

Article Info:

Accepted 21 Oktober 2019

Published Online 30 November 2019

(c) IICET Journal Publication, 2019

\begin{abstract}
Abstratc
This study purpose to describe marital readiness students in terms of gender, cultural background and socioeconomic conditions. The total sample was 90 people Guidance and Counseling students at the State University of Padang Faculty of Education selected by purposive random sampling technique. The Instrument was a questionary data analyzed by Analysis of Variance (ANOVA). The result showed the level of marital readiness in terms gender, cultural background and socio-economic conditions were in the average category.
\end{abstract}

Keyword: marital readiness, gender, cultural background, socio-economic conditions

This is an open access article distributed under the Creative Commons Attribution License, which permits unrestricted use, distribution, and reproduction in any medium, provided the original work is properly cited. (C2019 by author

\section{PENDAHULUAN}

Masa dewasa merupakan waktu yang paling lama dalam rentang kehidupan manusia yang dimulai dari usia 18 tahun sampai individu itu meninggal dunia (Yahya, 2012:245). Seperti yang dijelaskan oleh Feldman (dalam Santrock, 2007:6) masa dewasa terbagi menjadi tiga tahapan yaitu masa dewasa awal (early adulthood) dimulai dari usia 20 tahun hingga sekitar usia 40-45 tahun, masa dewasa pertengahan (middle adulthood) berlangsung dari usia 40-45 sampai usia 65 tahun, masa dewasa lanjut (old age) berlangsung dari usia 65 tahun sampai meninggal. Mahasiswa pada umumnya berada pada masa dewasa awal. Tidak hanya memiliki tugas dan tanggung jawab akademik, karier dan bagian dari masyarakat sosial, mahasiswa juga harus memenuhi tugastugas perkembangannya sebagai dewasa awal. Salah satu tugas perkembangan yang harus diselesaikan mahasiswa pada masa dewasa awal, yaitu menikah dan membina hubungan rumah tangga. Selain itu, Kenniston (dalam Syamsu Yusuf \& Nani M. Sugandi, 2012:117) mengemukakan dua kriteria penting untuk menunjukkan permulaan dari dewasa awal, yaitu kemandirian ekonomi dan kemandirian dalam membuat keputusan. Kemandirian ekonomi ditandai dengan pekerjaan yang berpenghasilan yang dimiliki oleh individu yang telah memasuki usia dewasa. Sedangkan kemandirian dalam mengambil keputusan ditandai dengan kemantapan individu dalam mengambil keputusan yang berhubungan dengan cinta atau pasangan hidup. Salah satu keputusan yang terkait dengan cinta atau pasangan hidup yaitu pernikahan.

Undang-Undang Republik Indonesia (UU RI) Nomor 1 tahun 1974 tentang perkawinan, meyatakan perkawinan adalah "ikatan lahir dan batin antara seorang pria dan wanita sebagai suami istri dengan tujuan membentuk keluarga (rumah tangga) yang bahagia dan kekal berdasarkan ketuhanan yang Maha Esa”. Dari penjelasan tersebut jelaslah bahwa pernikahan tidak hanya mempunyai keluarga yang bahagia dan kekal, namun 
yang terpenting mempunyai nilai yang luhur karena dilandasi ketuhanan Yang Maha Esa. Kemudian, Hurlock (2012) mengungkapkan pernikahan adalah pola yang normal dalam kehidupan individu dewasa. Menikah merupakan saat yang penting dalam siklus kehidupan manusia, selain sebagai pemenuhan kebutuhan seksual, pernikahan juga dapat memenuhi kebutuhan psikologis seseorang seperti rasa kasih sayang, rasa aman dan rasa ingin dihargai. Seperti yang dijelaskan oleh Walgito (2010) pernikahan dilakukan manusia untuk memenuhi kebutuhan psikologis, seksual, material dan spiritual. Sebelum memasuki kehidupan pernikahan, individu akan melewati proses pemilihan jodoh. Proses pemilihan jodoh sangat kompleks. Lewis \& Landis (dalam Prayitno, 2006:33) menjelaskan salah satu pertimbangan dalam memilih jodoh, yaitu kesiapan untuk menikah.

Duvall dan Miller (1985) mengemukakan kesiapan menikah merupakan keadaan siap atau bersedia dalam berhubungan dengan pasangan, siap menerima tanggung jawab sebagai suami atau istri, siap terlibat dalam hubungan seksual, siap mengatur keluarga, dan siap mengasuh anak.. Selama ini banyak pasangan yang hendak menikah memandang kesiapan menikah sebagai persiapan untuk melaksanakan persta pernikahan, padahal kesiapan menikah sejatinya adalah kesiapan lahir batin menghadapi bahtera rumah tangga. Blood (1987) menjelaskan kesiapan menikah terdiri dari kesiapan pribadi (personal readiness) dan kesiapan situasi (circumstantial readiness). Kesiapan pribadi meliputi kematangan emosi (emotional maturity), kesiapan fisik (old enough to get married), kematangan sosial (social maturity), emosi yang sehat (emotional health) dan kesiapan model peran (role preparation). Kesiapan situasi meliputi kesiapan finansial (financial resources) dan kesiapan waktu (resources of time). Bila mahasiswa telah dapat memenuhi kedua aspek tersebut dapat dikatakan mahasiswa tersebut telah memiliki kesiapan untuk menikah.

Wardhani \& Mashoedi (2012:92) mengemukakan faktor-faktor yang mempengaruhi kesiapan menikah, yaitu usia dan tingkat kedewasaan, waktu pernikahan, motif untuk menikah, dan kesiapan untuk memiliki hubungan seksual yang ekslusif, emansipasi emosional dari orangtua, pendidikan dan kesiapan pekerjaan. Selain itu, Walgito (2010) juga mengungkapkan beberapa faktor yang juga mempengaruhi kesiapan menikah, yaitu faktor fisiologis, faktor psikologis, faktor spiritual, faktor sosial. Selanjutnya, Fatimah (2010:189) menyebutkan faktor lain yang dijadikan pertimbangan dalam menetapkan pasangan hidup adalah kesamaan-kesamaan dalam hal ras, bangsa, agama dan status sosial ekonomi. Khusus tentang faktor sosial ekonomi mencakup berbagai aspek, antara lain menyangkut masalah pergaulan dan pekerjaan. Dari beberapa pendapat ahli, dapat diketahui beberapa faktor yang mempengaruhi kesiapan menikah mahasiswa diantaranya yaitu jenis kelamin, latar belakang budaya dan sosial ekonomi.

Idealnya individu yang telah memasuki usia dewasa awal khususnya mahasiswa telah memiliki kesiapan untuk menikah. Namun, kenyataan yang ditemui di lapangan masih ditemukan mahasiswa yang belum siap untuk menikah. Dari hasil wawancara yang penulis lakukan pada 10 orang mahasiswa BK yang dilakukan pada tanggal 5 September 2018 diperoleh informasi bahwa mahasiswa yang sudah memasuki usia dewasa awal ini belum siap untuk menikah bahkan masih belum memikirkan hal-hal yang berkaitan dengan pernikahan. Selain itu, rata-rata mahasiswa masih belum siap untuk menikah pada aspek kesiapan pribadi dan kesiapan situasi.Pada aspek kesiapan pribadi mahasiswa menyebutkan belum siap untuk menikah karena masih takut dan masih belum mampu untuk berperan sebagai suami atau istri. Selanjutnya, mereka mengungkapkan belum siap untuk menikah karena mereka belum siap untuk melakukan hubungan seksual secara intim dengan pasangannya kelak. Selain itu, pada aspek kesiapan situasi, mereka mengemukakan belum mampu untuk menikah karena belum memiliki pekerjaan sehingga belum mapan untuk memenuhi kebutuhan keluarganya kelak.

Hasil penelitian Kenedi, G (2005) tentang model konseling pranikah berorientasi pengembangan konsep diri, juga mengemukakan bahwa mahasiswa belum mampu bertindak sesuai dengan pertimbangan yang positif dalam mempersiapkan diri untuk menikah. Di samping itu pula mahasiswa belum mampu membuat komitmen pernikahan yang tegas, yang dapat mereka pegang kuat sebagai prinsip, sehingga mereka tidak mandiri dan tidak percaya diri. Pendirian mereka mudah goyah dan mudah berubah bila mendapat tekanan atau pengaruh dari lingkungannya serta merekapun tidak mampu membuat rencana untuk masa depan pernikahannya yang baik. Sebagian kecil merasa didesak orangtua untuk segera menikah, walaupun masih gelisah karena belum memiliki calon pasangan hidup dan masih bingung memilih kriteria yang sesuai harapan (Sugandi, 2010). Hal ini menunjukkan bahwa pernikahan mendapat perhatian besar dari masyarakat dan diharapkan setiap individu dewasa mengalaminya.

Studi longitudinal (dalam Papalia, 2014:130) mengungkapkan saat ini jumlah dewasa awal yang tidak memiliki rasa percaya diri untuk membangun sebuah hubungan intim meningkat. Selain itu, Kartono (1992:8) juga menyebutkan banyak wanita yang sangat menderita dan tidak berbahagia dalam perkawinan, sebenarnya bukan disebabkan oleh status perkawinan itu, akan tetapi disebabkan oleh tidak siap dan kurangnya kemampuan 
wanita tersebut memainkan beberapa peranan atau peranan ganda yang berbeda- beda dalam status perkawinan.Beberapa fenomena tersebut mengindikasikan bahwa masih ada mahasiswa yang belum memiliki kesiapan untuk menikah. Padahal kesiapan menikah itu sangat penting untuk dapat menjalankan kehidupan berkeluarga dengan bahagia, damai dan harmonis. Permasalahan itu perlu ditanggulangi, dan untuk menanggulanginya mahasiswa dapat diberikan layanan konseling di perguruan tinggi.

Layanan konseling pernikahan ini sangat diperlukan untuk memberikan kesiapan kepada calon pasangan suami/istri untuk dapat membangun rumah tangga yang bahagia dan harmonis. Yusuf dan Sugandi (2011: 133) mengungkapkan bahwa kesiapan diri untuk menikah sangat diperlukan dengan tujuan agar masing- masing pasangan dapat mengetahui, memahami, serta menyikapi nilai-nilai pernikahan yang merujuk kepada makna dan hikmah pernikahan dalam hidup berkeluarga. Selanjutnya, Stanley dkk, 2006 (dalam Papalia, 2014: 139) mengungkapkan pasangan yang melakukan konseling sebelum penikahan cenderung menjadi lebih puas dan berkomitmen dalam pernikahan mereka dibandingkan dengan pasangan yang tidak melakukan konseling dan pernikahan mereka berakhir di perceraian. Wirdhana, dkk (2013:54) mengungkapkan bahwa pasangan yang memiliki kesiapan untuk menjalani kehidupan perkawinan akan lebih mudah menerima dan menghadapi segala konsekuensi persoalan yang timbul dalam perkawinan.

Untuk itu, kegiatan layanan ini seharusnya dapat diterapkan dilingkungan masyarakat, salah satunya di perguruan tinggi yang mana ditujukkan kepada mahasiswa dan orang-orang yang berada di lingkungan perguruan tinggi yang sedang mempersiapkan dirinya untuk menikah. Konselor dan personil layanan mahasiswa pada layanan konseling di perguruan tinggi menekankan pada hal-hal yang umum mengenai perkembangan total dari orang-orang yang mereka layani (Gladding, 2012:449), termasuk mengenai tugas perkembangan mahasiswa untuk siap memilih dan mencegah terjadinya masalah serta pengentasan masalah berkaitan dengan pernikahan.Berdasarkan permasalahan yang telah dikemukakan maka tujuan penelitian ini adalah (1) mendeskripsikan kesiapan menikah mahasiswa BK FIP UNP ditinjau dari jenis kelamin laki-laki dan perempuan serta perbedaannya, (2) mendeskripsikan kesiapan menikah mahasiswa BK FIP UNP ditinjau dari latra belakang budaya yaitu Matriarkhat dan Patriarkhat serta perbedaannya, (3) mendeskripsikan kesiapan menikah mahasiswa BK FIP UNP ditinjau dari kondisi sosial ekonomi serta perbedaannya, (4) mendeskripsikan kesiapan menikah mahasiswa ditinjau dari jenis kelamin, latar belakang budaya dan kondisi sosial ekonomi serta interaksinya.

\section{METODE}

Jenis penelitian ini adalah deskriptif komparatif. Bertujuan untuk mendeskripsikan kesiapan menikah mahasiswa (Y) ditinjau dari jenis kelamin (X1), latar belakang budaya (X2) dan sosial ekonomi (X3). Populasi penelitian ini adalah mahasiswa BK FIP UNP yang berjumlah 796 orang mahasiswa dari tahun masuk 2014 sampai dengan tahun masuk 2018. jumlah sampel sebanyak 90 orang dengan teknik proportional random sampling. Instrumen penelitian ini adalah angket dengan model skala Likert. Data dianalisis dengan menggunakan teknik analisis varian (ANAVA) dan mengolah data menggunakan SPSS versi 20.00.

\section{HASIL PENELITIAN}

Berdasarkan pengolahan data yang telah dilakukan, maka data hasil penelitian disajikan dan dianalisis sesuai dengan tujuan penelitian yang diajukan sebelumnya, yaitu untuk mendeskripsikan kesiapan menikah mahasiswa BK FIP UNP ditinjau dari jenis kelamin, yaitu jenis kelamin laki-laki dan perempuan, mendeskripsikan kesiapan menikah mahasiswa BK FIP UNP ditinjau dari latar belakang budaya, yaitu Matriarkhat dan Patriarkhat, mendeskripsikan kesiapan menikah mahasiswa BK FIP UNP ditinjau dari kondisi ekonomi, yaitu yang telah memiliki pekerjaan tetap dan tidak memiliki pekerjaan tetap, mendeskripsikan kesiapan menikah mahasiswa BK FIP UNP bila ditinjau dari jenis kelamin dan latar belakang budaya secara bersamaan, mendeskripsikan kesiapan menikah mahasiswa BK FIP UNP bila ditinjau dari jenis kelamin dan kondisi ekonomi secara bersamaan, mendeskripsikan kesiapan menikah mahasiswa BK FIP UNP bila ditinjau latar belakang budaya dan kondisi ekonomi secara bersamaan, mendeskripsikan kesiapan menikah mahasiswa BK FIP UNP bila ditinjau dari interaksi antara jenis kelamin, latar belakang budaya, dan kondisi ekonomi.

Rancangan penelitian menggunakan desain faktorial $2 \times 2 \times 2$. Unit-unit objek penelitian dikelompokkan ke dalam tabel yang diatur secara proporsional sehingga unit-unit objek bersifat homogen. Desain penelitian kesiapan menikah mahasiswa ditinjau dari jenis kelamin, latar belakang budaya dan kondisi sosial ekonomi dapat dikelompokkan ke dalam tabel berikut.

Tabel 1. Desain Model Faktorial ex post facto 2 × 2 × 2 


\begin{tabular}{|c|c|c|c|}
\hline \multirow[b]{2}{*}{$\begin{array}{c}\text { Jenis Kelamin } \\
\text { (A) }\end{array}$} & \multirow[b]{2}{*}{$\begin{array}{c}\text { Latar Belakang } \\
\text { Budaya (B) }\end{array}$} & \multicolumn{2}{|c|}{ Kondisi Sosial Ekonomi (C) } \\
\hline & & $\begin{array}{l}\text { Pekerjaan } \\
\text { Orangtua } \\
\text { (C1) }\end{array}$ & $\begin{array}{l}\text { Pekerjaan Orangtua } \\
\text { tidak Tetap (C2) }\end{array}$ \\
\hline \multirow{2}{*}{ Laki-1aki (A1) } & $\begin{array}{l}\text { Patriarkhat } \\
\text { (B1) }\end{array}$ & 1. (A1B1C1) & 2. (A1B1C2) \\
\hline & $\begin{array}{l}\text { Matriarkhat } \\
\text { (B2) }\end{array}$ & 3. $(\mathrm{A} 1 \mathrm{~B} 2 \mathrm{C} 1)$ & 4. (A1B2C2) \\
\hline \multirow{2}{*}{$\begin{array}{l}\text { Perempuan } \\
\text { (A2) }\end{array}$} & $\begin{array}{l}\text { Patriarkhat } \\
\text { (B1) }\end{array}$ & 5. (A2B1C1 & 6. (A2B1C2) \\
\hline & $\begin{array}{l}\text { Matriarkhat } \\
\text { (B2) }\end{array}$ & 7. (A2B2C1) & 8. $(\mathrm{A} 2 \mathrm{~B} 2 \mathrm{C} 2)$ \\
\hline
\end{tabular}

Keterangan:

1. (A1B1C1): Mahasiswa laki-laki latar belakang budaya Patriarkhat pekerjaan orangtua tetap

2. (A1B1C2): Mahasiswa laki-laki latar belakang budaya Patriarkhat pekerjaan orangtua tidak tetap

3. (A1B2C1): Mahasiswa laki-laki latar belakang budaya Matriarkhat pekerjaan orangtua tetap

4. (A1B2C2): Mahasiswa laki-laki latar belakang budaya Matriarkhat pekerjaan orangtua tidak tetap

5. (A2B1C1): Mahasiswa perempuan latar belakang budaya Patriarkhat pekerjaan tetap

6. (A2B1C2) : Mahasiswa perempuan latar belakang budaya Patriarkhat pekerjaan orangtua tidak tetap

7. (A2B2C1): Mahasiswa perempuan latar belakang budaya Matriarkhat pekerjaan orangtua tetap

8. (A2B2C2): Mahasiswa perempuan latar belakang budaya Matriarkhat pekerjaan orangtua tidak tetap

Data kesiapan menikah mahasiswa secara keseluruhan diperoleh dari sampel (responden) yang berjumlah 90 orang mahasiswa BK. Berikut penjabaran data kesiapan menikah mahasiswa secara keseluruhan.

Tabel 2. Deskripsi Kesiapan Menikah Mahasiswa Ditinjau dari Jenis Kelamin, Latar Belakang Budaya, dan Sosial Ekonomi (n=90)

\begin{tabular}{|c|c|c|c|c|c|c|c|}
\hline $\begin{array}{c}\text { Jenis } \\
\text { Kelamin }\end{array}$ & $\begin{array}{c}\text { Latar } \\
\text { Belakang } \\
\text { Budaya }\end{array}$ & $\begin{array}{c}\text { Sosial } \\
\text { Ekonomi }\end{array}$ & $\mathbf{n}$ & Mean & SD & $\%$ & Kategori \\
\hline \multirow[t]{4}{*}{ Laki-laki } & \multirow[t]{2}{*}{ Patriarkhat } & $\begin{array}{l}\text { Pekerjaan } \\
\text { orangtua } \\
\text { tetap }\end{array}$ & 3 & 122,67 & 10,41 & 70,10 & Sedang \\
\hline & & $\begin{array}{l}\text { Pekerjaan } \\
\text { orangtua } \\
\text { tidak } \\
\text { tetap }\end{array}$ & 8 & 132,00 & 13,42 & 74,10 & Sedang \\
\hline & \multirow[t]{2}{*}{ Matriarkhat } & $\begin{array}{l}\text { Pekerjaan } \\
\text { orangtua } \\
\text { tetap }\end{array}$ & 9 & 131,11 & 16,36 & 74,92 & Sedang \\
\hline & & $\begin{array}{l}\text { Pekerjaan } \\
\text { orangtua } \\
\text { tidak } \\
\text { tetap } \\
\end{array}$ & 15 & 134,07 & 11,54 & 76,94 & Sedang \\
\hline \multirow[t]{4}{*}{ Perempuan } & \multirow[t]{2}{*}{ Patriarkhat } & $\begin{array}{l}\text { Pekerjaan } \\
\text { orangtua } \\
\text { tetap }\end{array}$ & 7 & 133,00 & 11,87 & 76,00 & Sedang \\
\hline & & $\begin{array}{l}\text { Pekerjaan } \\
\text { orangtua } \\
\text { tidak } \\
\text { tetap }\end{array}$ & 23 & 128,56 & 12,56 & 73,29 & Sedang \\
\hline & \multirow[t]{2}{*}{ Matriarkhat } & $\begin{array}{l}\text { Pekerjaan } \\
\text { orangtua } \\
\text { tetap }\end{array}$ & 15 & 139,13 & 12,79 & 79,50 & Sedang \\
\hline & & $\begin{array}{l}\text { Pekerjaan } \\
\text { orangtua } \\
\text { tidak } \\
\text { tetap } \\
\end{array}$ & 10 & 129,40 & 15,34 & 74,11 & Sedang \\
\hline \multicolumn{3}{|c|}{ Total } & 90 & 131,02 & 13,00 & 74,87 & Sedang \\
\hline
\end{tabular}

Dari tabel 2 dapat dipahami bahwa tingkat kesiapan menikah mahasiswa ditinjau dari jenis kelamin, latar belakang budaya dan sosial ekonomi secara keseluruhan berada pada kategori tinggi (T) dengan rata-rata skor (mean) 131,02 dan persentase capaian terhadap skor ideal sebesar 74,87 \%. Rata-rata skor (mean) kesiapan menikah yang paling tinggi adalah mahasiswa BK perempuan dengan latar belakang budaya Matriarkhat dan pekerjaan orangtuanya tetap dengan rata-rata skor 139,13 dan persentase capaian terhadap skor ideal sebesar $79,50 \%$. Rata-rata skor (mean) kesiapan menikah yang paling rendah adalah mahasiswa BK laki-laki dengan latar belakang budaya Patriarkhat dan pekerjaan orangtua tidak tetap dan rata-rata skor 122,67 dan persentase capaian terhadap skor ideal sebesar 70,10\%. 
Selanjutnya, hasil pengujian hipotesis gabungan variabel jenis kelamin, latar belakang budaya dan kondisi sosial ekonomi melalui analisis varian dapat dilihat dalam beberapa kombinasi variabel yang dijabarkan sebagai berikut.

\begin{tabular}{|c|c|c|c|c|c|c|}
\hline Sumber Variansi & Jk & Db & $\mathbf{R k}$ & $\mathbf{F e}_{\mathrm{e}}$ & Sig. & Ket. \\
\hline $\begin{array}{ll}\text { Skor Mahasiswa } \\
\text { Laki-1aki dan } \\
\text { Perempuan }\end{array}$ & 106,304 & 1 & 106,304 &, 612 & .436 & $\begin{array}{c}\text { Tidak } \\
\text { Signifikan }\end{array}$ \\
\hline $\begin{array}{l}\text { Skor Mahasiswa } \\
\text { budaya } \\
\text { Patriarkhat dan } \\
\text { Matriarkhat }\end{array}$ & 308.886 & 1 & 308,886 & 1,779 & -186 & $\begin{array}{c}\text { Tidak } \\
\text { Signifíkan }\end{array}$ \\
\hline $\begin{array}{l}\text { Skor Mahasiswa } \\
\text { pekerjaan } \\
\text { orangtua tetap } \\
\text { dan pekerjaan } \\
\text { orangtua tidak } \\
\text { tetap }\end{array}$ & 3,570 & 1 & 3,570 & 0,021 & .886 & $\begin{array}{c}\text { Tidak } \\
\text { Signifikan }\end{array}$ \\
\hline $\begin{array}{lc}\text { Interaksi variabel } \\
\text { jenis } & \text { kelamin } \\
\text { dengan } & \text { latar } \\
\text { belakang budaya }\end{array}$ & 12,691 & 1 & 12,691 & .073 & .788 & $\begin{array}{c}\text { Tidak } \\
\text { Signifúkan }\end{array}$ \\
\hline $\begin{array}{l}\text { Interaksi variabel } \\
\text { jenis kelamin dan } \\
\text { sosial ekonomi }\end{array}$ & 707.677 & 1 & 707.677 & 4.077 & .047 & Signifikan \\
\hline $\begin{array}{l}\text { Interaksi variabel } \\
\text { latar belakang } \\
\text { budaya dan sosial } \\
\text { ekonomi }\end{array}$ & 137.837 & 1 & 137.837 & .794 & .375 & $\begin{array}{c}\text { Tidak } \\
\text { Signifikan }\end{array}$ \\
\hline $\begin{array}{l}\text { Interaksi variabel } \\
\text { jenis kelamin, } \\
\text { latar belakang } \\
\text { budaya dan sosial } \\
\text { ekonomi }\end{array}$ & 1,178 & 1 & 1,178 &, 007 & .935 & $\begin{array}{c}\text { Tidak } \\
\text { Signifitkan }\end{array}$ \\
\hline
\end{tabular}

Berdasarkan Tabel 3 dapat ditarik kesimpulan penelitian sebagai berikut.

Tidak terdapat perbedaan yang signifikan pada kesiapan menikah mahasiswa BK FIP UNP bila ditinjau dari jenis kelamin. Berarti bahwa perbedaan jenis kelamin laki-laki dan perempuan tidak menentukan kesiapan menikah mahasiswa. Hal ini ditunjukkan oleh nilai $\mathrm{F}_{\text {hitung }}$ yang diperoleh yaitu sebesar 0.612, sedangkan Sig. pada derajat kebebasan (db) 1 dan aplha $(\alpha) 0.05$ bernilai 0.436 , maka sesuai dengan kriteria pengujian hipotesis melalui analisis varian (ANAVA), Sig. lebih besar dari 0.05 yang berarti bahwa tidak terdapat perbedaan yang signifikan antara kesiapan menikah mahasiswa BK FIP UNP yang berasal dari jenis kelamin laki-laki dan perempuan.

Tidak terdapat perbedaan yang signifikan pada kesiapan menikah mahasiswa BK FIP UNP bila ditinjau dari latar belakang budaya. Berarti bahwa perbedaan budaya Patriarkhat dan Matriarkhat tidak menentukan kesiapan menikah mahasiswa. Hal ini ditunjukkan oleh nilai $\mathrm{F}_{\text {hitung }}$ yang diperoleh yaitu sebesar 1.799, sedangkan Sig. pada derajat kebebasan $(\mathrm{db}) 1$ dan aplha $(\alpha) 0.05$ bernilai 0.186 , maka sesuai dengan kriteria pengujian hipotesis melalui analisis varian (ANAVA), Sig. lebih besar dari 0.05 yang berarti bahwa tidak terdapat perbedaan yang signifikan antara kesiapan menikah mahasiswa BK FIP UNP yang berasal dari latar belakang budaya Patriarkhat dan Matriarkhat.

Tidak terdapat perbedaan yang signifikan pada kesiapan menikah mahasiswa BK FIP UNP bila ditinjau dari sosial ekonomi. Berarti bahwa perbedaan sosial ekonomi pekerjaan orangtua tetap dan pekerjaan orangtua tidak tetap tidak menentukan kesiapan menikah mahasiswa. Hal ini ditunjukkan oleh nilai $\mathrm{F}_{\text {hitung }}$ yang diperoleh yaitu sebesar 0.021, sedangkan Sig. pada derajat kebebasan (db) 1 dan aplha $(\alpha) 0.05$ bernilai 0.886, maka sesuai dengan kriteria pengujian hipotesis melalui analisis varian (ANAVA), Sig. lebih besar dari 0.05 yang berarti bahwa tidak terdapat perbedaan yang signifikan antara kesiapan menikah mahasiswa BK FIP UNP yang berasal dari ekonomi pekerjaan orangtua tetap dan pekerjaan orangtua tidak tetap.

Tidak terdapat interaksi antara jenis kelamin dan latar belakang budaya dalam menjelaskan kesiapan menikah mahasiswa BK FIP UNP. Hal ini ditunjukkan oleh nilai $F_{\text {hitung }}$ yang diperoleh yaitu sebesar 0.073, sedangkan Sig. pada derajat kebebasan (db) 1 dan aplha $(\alpha) 0.05$ bernilai .788, maka sesuai dengan kriteria pengujian hipotesis melalui analisis varian (ANAVA), Sig. lebih besar dari 0.05 yang berarti bahwa tidak terdapat perbedaan yang signifikan interaksi antara jenis kelamin dan latar belakang budaya dalam menjelaskan kesiapan menikah mahasiswa BK FIP UNP.

Terdapat interaksi antara jenis kelamin dengan sosial ekonomi dalam menjelaskan kesiapan menikah mahasiswa BK FIP UNP. Berarti bahwa interaksi jenis kelamin dan kondisi sosial ekonomi menentukan kesiapan menikah mahasiswa BK FIP UNP. Hal ini ditunjukkan oleh nilai $\mathrm{F}_{\text {hitung }}$ yg diperoleh yaitu sebesar 4.077, sedangkan Sig. pada derajat kebebasan (db) 1 dan aplha $(\alpha) 0.05$ bernilai .047 , maka sesuai dgn kriteria pengujian hipotesis melalui analisis varian (ANAVA), Sig. kurang dari 0.05 yang berarti bahwa terdapat perbedaan yang signifikan antara kesiapan menikah mahasiswa BK FIP UNP bila ditinjau dari jenis kelamin dan kondisi ekonomi secara bersamaan (interaksi). 
Tidak terdapat interaksi latar belakang budaya dan kondisi sosial ekonomi dalam menjelaskan kesiapan menikah mahasiswa BK FIP UNP. Berarti bahwa interaksi latar belakang budaya dan kondisi sosial ekonomi tidak menentukan kesiapan menikah mahasiswa BK FIP UNP. Hal ini ditunjukkan oleh nilai $\mathrm{F}_{\text {hitung }}$ yang diperoleh yaitu sebesar 0.794, sedangkan Sig. pada derajat kebebasan (db) 1 dan aplha $(\alpha) 0.05$ bernilai 0.375 , maka sesuai dengan kriteria pengujian hipotesis melalui analisis varian (ANAVA), Sig. lebih besar dari 0.05 yang berarti bahwa tidak terdapat perbedaan yang signifikan antara kesiapan menikah mahasiswa BK FIP UNP bila ditinjau dari latar belakang budaya dan kondisi ekonomi secara bersamaan (interaksi).

Tidak terdapat interaksi jenis kelamin, latar belakang budaya dan kondisi sosial ekonomi dalam menjelaskan kesiapan menikah mahasiswa BK FIP UNP. Berarti bahwa interaksi jenis kelamin, latar belakang budaya dan kondisi sosial ekonomi tidak menentukan kesiapan menikah mahasiswa BK FIP UNP. Hal ini ditunjukkan oleh nilai $F_{\text {hitung }}$ yang diperoleh yaitu sebesar 0.07 , sedangkan Sig. pada derajat kebebasan (db) 1 dan aplha $(\alpha) 0.05$ bernilai 0.935 , maka sesuai dengan kriteria pengujian hipotesis melalui analisis varian (ANAVA), Sig. lebih besar dari 0.05 yang berarti bahwa tidak terdapat perbedaan yang signifikan antara kesiapan menikah mahasiswa BK FIP UNP bila ditinjau dari jenis kelamin, latar belakang budaya dan kondisi ekonomi secara bersamaan (interaksi).

\section{PEMBAHASAN}

Pembahasan yang akan dijabarkan ini berdasarkan kepada rumusan masalah dan tujuan dalam penelitian yang telah dikemukakan yaitu:

\section{Gambaran Kesiapan Menikah Mahasiswa Ditinjau dari Jenis Kelamin Laki-laki dan Perempuan serta Perbedaannya}

Secara umum konsep seks atau jenis kelamin mangacu pada perbedaan biologis antara perempuan dan laki-laki; pada perbedaan antara tubuh laki-laki dan perempuan. Dapat dipahami bahwa definisi konsep seks menekankan pada perbedaan biologis antara pria dan wanita yang disebabkan oleh perbedaan kromosom pada janin (Kamanto, 2011:147). Duvall dan Miller (1985:22) mengemukakan bahwa pada umumnya perempuan mulai masuk sekolah pada usia 6 tahun, memasuki remaja pada usia 13 tahun dan menikah lebih kurang pada usia 23 tahun. Anak pertama lahir sebelum usia mereka 30 tahun. Sedangkan perempuan yang belajar di perguruan tinggi akan menikah terlambat, memiliki anak pertama juga pada waktu yang terlambat dan memasuki tahap berikutnya dari siklus kehidupan keluarga terlambat dari perempuan yang tidak berpendidikan. Pada laki-laki mereka juga mulai masuk sekolah pada umur 6 tahun dan menjadi remaja pada usia 13 tahun. Mereka menikah dua tahun lebih lambat daripada perempuan, yaitu lebih kurang pada usia 25 tahun. Pada usia ini mereka mulai berpenghasilan untuk keluarganya. Anak pertama lahir ketika berumur 27 tahun dan anak terakhir mereka lahir ketika mereka berumur 32 tahun. Mereka akan menjadi ayah dari anak-anak remaja ketika berusia 40 tahun. Penelitian ini membahasas kesiapan menikah dilihat dari perbedaan jenis kelamin yaitu jenis kelamin laki-laki dan perempuan.

Hasil analisis data menunjukkan bahwa tingkat kesiapan menikah mahasiswa laki-laki dan perempuan berada pada kategori sedang (S). Dilihat secara detail dari hasil analisis data pada kesiapan menikah mahasiswa BK FIP UNP laki-laki dan perempuan tampak bahwa aspek nilai rata-rata tertinggi yaitu aspek kesiapan pribadi dibanding dengan aspek kesiapan situasi. Hasil penelitian yang dilakukan oleh Diah Krisnatuti dan Vivi Oktaviani (2010) dengan judul penelitian "Persepsi dan Kesiapan Menikah pada Mahasiswa". Hasil penelitian tersebut mengungkapkan kesiapan menikah laki-laki dan perempuan berada pada kategori sedang dan tidak terdapat perbedaan yang nyata antara persepsi terhadap pernikahan pada partisipan laki-laki dan perempuan. Selanjutnya, Sanni Sahara, dkk (2012) dengan judul penelitian " Model Paket Layanan Penguasaan Konten Bertema Kesiapan Menikah Berbasis Multimedia pada Mahasiswa”. Penelitian ini mengungkapkan secara umum tingkat kesiapan menikah mahasiswa berada pada kategori rendah. Kemudian, Sari \& Sunarti (2013) dengan judul penelitian "Kesiapan Menikah pada Dewasa Muda dan Pengaruhnya terhadap Usia Menikah". Penelitian tersebut mengungkapkan kesiapan menikah mahasiswa secara umum berada pada kategori rendah. Selain itu, Nurlita Tsania, Euis Sunarti, dan Diah Krisnatuti (2015) dengan judul penelitian "Karakteristik Keluarga, Kesiapan Menikah Istri, dan Perkembangan Anak Usia 3-5 Tahun". Penelitian tersebut mengungkapkan tingkat kesiapan menikah mahasiswa berada pada kategori rendah terutama pada aspek finansial dan intelektual.

Dari beberapa hasil penelitian terdahulu tingkat kesiapan menikah mahasiswa berada pada kategori sedang dan rendah. Hal ini dikarenakan, secara fitrah merupakan tugas perkembangan pada individu yang mulai memasuki usia dewasa awal untuk memilih pasangan hidup dan belajar hidup dengan pasangan dalam ikatan pernikahan karena telah memiliki kesiapan pribadi khususnya dalam hal kesiapan untuk berhubungan seksual yg sedang, namun pernikahan belum dilakukan mahasiswa BK FIP UNP yang telah memasuki usia dewasa awal 
karena beberapa faktor lain yg mempengaruhinya. Hasil penelitian yang dilakukan oleh Nini Oktaviani (2014) mengenai faktor penyebab orang dewasa awal menunda pernikahan. Hasil penelitian tersebut mengungkapkan faktor yang menjadi penyebab dewasa awal menunda perkawinan yaitu sering gagal dalam mencari pasangan, tidak mencapai usia kematangan yang sebenarnya, jarang mempunyai kesempatan untuk berkumpul dengan lawan jenis yang dianggap cocok dan sepadan, identifikasi yang ketat terhadap orangtua, egosentrisme dan narsisme yang berlebihan, musim pasang dari kebudayaan individualisme, karena mempunyai tanggung jawab keuangan dan waktu terhadap orangtua dan saudara-saudaranya, trauma perceraian yang dialami keluarga, serta terlanjur memikirkan karir.

Maka untuk itu, perlu upaya untuk mempersiapkan mahasiswa BK FIP UNP laki-laki dan perempuan untuk menikah melalui pelayanan BK di perguruan tinggi terutama yang berkaitan dengan kesiapan situasi yaitu dalam hal kesiapan finansial dan kesiapan waktu dalam kehidupan berkeluarga nantinya, karena nilai ratarata aspek ini lebih rendah dari aspek lainnya dalam kesiapan menikah, maka apabila ini dibiarkan dikhawatirkan akan menimbulkan efek yang kurang baik setelah mahasiswa BK FIP UNP menikah. Hal ini bisa jadi disebabkan karena perbedaan pandangan laki-laki dan perempuan mengenai pernikahan, hasil penelitian Light dan Keller (dalam Fatimah,2010:189) bahwa 60\% wanita menyatakan bahwa pernikahan itu didorong oleh faktor cinta dan keintiman, namun laki-lai $70 \%$ menyatakan bahwa pernikahan adalah masalah faktor keinginan hidup bersama dan mengurangi ketegangan, sedang faktor dorongan cinta menduduki urutan ketiga

\section{Gambaran Kesiapan Menikah Mahasiswa Ditinjau dari Latar Belakang Budaya Patriarkhat dan Matriarkhat serta Perbedaannya}

Koentjaraningrat (2009:153) mengemukakan nilai budaya berfungsi sebagai pedoman hidup manusia dalam masyarakat, tetapi sebagai konsep, suatu nilai budaya itu bersifat sangat umum, mempunyai ruang lingkup yang sangat luas. Kebudayaan di Indonesian sangat beragam, pada penelitian ini peneliti akan membahas budaya Patriarkhat dan budaya Matriarkhat. Patriarkhat merupakan sebuah sistem sosial yang menempatkan laki-laki sebagai sosok otoritas utama yang sentral dalam organisasi sosial (Siti Fatimah \& Wirdaningsih, 2016:99). Sedangkan Matriarkhat suatu sistem yang mengatur kehidupan dan ketertiban suatu masyarakat yang terikat dalam suatu jalinan kekerabatan dalam garis ibu. Penelitian ini membahas tentang tingkat kesiapan menikah mahasiswa dilihat dari perbedaan latar belakang budaya yaitu budaya Patriarkhat dan budaya Matriarkhat.

Hasil analisis data menunjukkan bahwa tingkat kesiapan menikah mahasiswa BK yang berlatar belakang budaya Patriarkhat dan Matriarkhat berada pada kategori sedang (S), skor rata-rata tertinggi terdapat pada aspek kesiapan pribadi, kemudian skor rata-rata terendah terdapat pada aspek kesiapan situasi, serta tidak terdapat perbedaan yang signifikan antara kesiapan menikah mahasiswa BK dari budaya Patriarkhat dan Matriarkhat.Salah satu faktor yang mempengaruhi kesiapan menikah adalah faktor budaya. Dalam memilih pasangan hidup, pertimbangan yang dipakai satu budaya akan berbeda dengan budaya yang lain, setiap masyarakat di dunia memiliki norma berkenaan dengan masalah perkawinan (Cashion, 1983:311). Hasil penelitian menujukkan bahwa tidak terdapat perbedaan kesiapan untuk menikah pada masing-masing budaya. Budaya adalah suatu cara hidup yang berkembang dan dimiliki bersama oleh sebuah kelompok orang dan diwariskan dari generasi ke generasi tidak terdapat perbedaan kesiapan menikah mahasiswa yang berasal dari budaya Patriarkhat dan Matriarkhat disebabkan karena masing-masing budaya memiliki perbedaan dan kekhasan masing-masing. Karenanya, budaya tidak dapat diperbandingkan, termasuk dalam hal kesiapan menikah.

Hasil penelitian menunjukkan bahwa kesiapan menikah laki-laki budaya Patriarkhat lebih tinggi dibandingkan dengan kesiapan menikah perempuan budaya Patriarkhat. Hal ini dapat terjadi karena budaya Patriarkhat menempatkan laki-laki lebih tinggi derajatnya dibanding perempuan. Pada masyarakat yang menganut kebudayaan Patriarkhat perempuan akan merasa sulit, namun perempuan yang melahirkan anak lakilaki memperoleh kedudukan yang tinggi. Dalam tata pernikahan status perempuan tampak lebih rendah. Adanya hak turunan dan waris dalam suku Batak pada anak laki-laki cenderung menimbulkan kemajuan bagi anak laki-laki. Kelebihan anak laki-laki tersebut mendorong kerinduan dari suatu pernikahan untuk melahirkan anak laki-laki. Kehadirannya dalam suatu keluarga memberi harapan tentang kelanjutan keturunan mereka. Disamping kelanjutan keturunan, kehadiran anak laki-laki dalam keluarga bisa meningkatkan kedudukan dan peranan ayah dan ibunya pada upacara adat (Manalu, dalam Nirwana, 2003:75). Oleh karena itu, kesiapan menikah laki-laki budaya Patriarkhat lebih tinggi daripada kesiapan menikah perempuan Patriarkhat.

Dalam budaya Matriarkhat yang dianut di Minangkabau, garis keturunan mengikuti ibu. Dalam masyarakat Minangkabau kedudukan laki-laki dan perempuan berada dalam posisi berimbang. Laki-laki punya hak untuk mengatur segala yang ada di dalam perkauman, baik pengturan pemkaian, pembagian harta pusaka, 
perempuan sebagai pemilik dapat mempergunakan semua hasil itu untuk keperluan anak beranak. Kehidupan dalam pernikahan dan berkeluarga tidak akan berjalan dengan mulus. Hal ini disebabkan masalah akan timbul selama kehidupan berjalan (Yendi, Ardi \& Ifdil, 2014). Perbedayaan budaya dalam kehidupan pernikahan dapat memicu timbulnya permasalahan. Masalah-masalah yang timbul dapat menyebabkan pasangan suami istri merasa tidak bahagia. Untuk mencegah timbulkan permasalahan dalam rumah tangga terutama dalam hal yang berkaitan dengan budaya, mahasiswa dapat melakukan konseling pernikahan.

Strategi pelayanan konseling dengan pengembangan locus of control pada klien-klien yang berorientasi pada kolektivisme yaitu konselor perlu mempertimbangkan etnis dan budaya klien (Marjohan, 2013). Senada dengan hal ini, strategi pelayanan konseling yang dapat digunakan konselor perguruan tinggi dalam memberikan pelayanan konseling kepada mahasiswa yaitu konselor perlu mempertimbangkan budaya klien/ mahasiswa sehingga pelayanan konseling tersebut dapat memberikan hasil yang optimal dan tidak bertentangan dengan budaya klien.Selanjutnya, pelayanan konseling diperguruan tinggi juga bertujuan untuk mencegah terjadinya kekerasan dalam rumah tangga (KDRT). Aina Rumiati Azis (dalam Afdal, 2015) mengemukakan KDRT yang terjadi pada perempuan disebabkan oleh (a) faktor budaya Patriarki yang mendudukkan laki-laki sebagai makhluk superior dan perempuan sebagai makhluk interior, (b) pemahaman keliru terhadap ajaran agama sehingga menganggap laki-laki boleh menguasai perempuan dan (c) peniruan laki-laki yang hidup bersama ayah yang suka memukul, biasanya akan meniru perilaku ayahnya.

\section{Gambaran Kesiapan Menikah Mahasiswa ditinjau dari Kondisi Sosial Ekomi Pekerjaan Orangtua Tetap dan Pekerjaan Orangtua Tidak Tetap serta perbedaannya}

Kondisi sosial ekonomi keluarga akan diwarnai oleh bagaimana interaksi sosial yang terjadi antara anggota keluarga dan interaksi sosial dengan masyarakat lingkungannya. Soekanto (2013) mengungkapkan komponen pokok kedudukan status sosial ekonomi meliputi: pendidikan, pekerjaan, pendapatan, tingkat pengeluaran dan pemenuhan kebutuhan. Penelitian ini akan mengungkapkan tingkat kesiapan menikah mahasiswa dilihat dari perbedaan kondisi sosial ekonomi orangtua yaitu pekerjaan orangtua tetap dan pekerjaan orangtua tidak tetap.

Hasil analisis data menunjukkan bahwa tingkat kesiapan menikah mahasiswa BK bila ditinjau dari kondisi sosial ekonomi pekerjaan orangtua tetap dan pekerjaan tidak tetap sama-sama berada pada kategori sedang (S), serta kesiapan menikah mahasiswa BK FIP UNP yang pekerjaan orangtuanya tetap ataupun pekerjaan orangtuanya tidak tetap skor rata-rata tertinggi terdapat pada aspek kesiapan pribadi, kemudian skor rata-rata terendah terdapat pada aspek kesiapan situasi, nilai tersebut masih dapat dimasukkan dalam kategori sedang. Dengan demikian dapat dipahami bahwa perlu upaya untuk mempertahankan dan meningkatkan pelayanan dalam BK terutama yang berkaitan dengan kesiapan situasi.

Faktor ekonomi pada setiap individu mempengaruhi terhadap kehidupan dalam keluarganya. Biaya hidup yang semakin tinggi dan biaya pendidikan yang semakin mahal, membuat lazimnya masyarakat indonesia baik laki-laki maupun perempuan bekerja untuk menunjang kehidupan ekonomi keluarga. Perekonomian keluarga merupakan salah satu aspek dalam menyiapkan kehidupan keluarga. Kesiapan secara ekonomi sangat diperlukan untuk memenuhi kebutuhan keluarga.

Gambaran Kesiapan Menikah Mahasiswa Ditinjau dari Jenis Kelamin, Latar Belakang Budaya, dan Kondisi Ekonomi serta Interaksi antar Variabel dalam Menjelaskan Kesiapan Menikah Mahasiswa

Dari hasil deskripsi data yang telah dikemukakan sebelumnya, dapat dipahami bahwa ditinjau dari jenis kelamin, latar belakang budaya dan kondisi sosial ekonomi tingkat kesiapan menikah mahasiswa BK FIP UNP berada pada kategori sedang (S). Temuan tersebut juga memberikan gambaran bahwa kesiapan menikah mahasiswa BK FIP UNP berada pada kategori yang positif, namun tetap dibutuhkan pelayanan BK yang mempertahankan dan meningkatkan kesiapan menikah mahasiswa. Kesiapan menikah mahasiswa dapat dipengaruhi oleh beberapa hal, diantaranya: jenis kelamin, latar belakang budaya dan kondisi sosial ekonomi. Senada dengan hal ini, Susi Hardianti, Pil Yanuar Kiram \& Syahniar (2014) menjelaskan tingkat kemampuan hubungan sosial ditinjau dari jenis kelamin dan latar belakang budaya berada pada kategori tinggi. Hasil penelitian ini memberikan sumbangan pengetahuan mengenai tingkat kemampuan hubungan sosial, salah satu bentuk hubungan sosial yaitu pernikahan. Sebelum melakukan pernikahan seyogyanya dewasa awal memiliki kesiapan agar pernikahan yang dilakukan harmonis dan terhindar dari perceraian.

Selain itu, untuk jenis kelamin tidak terdapat perbedaan kesiapan menikah antara laki-laki dan perempuan. Tingkat kesiapan menikah laki-laki lebih tinggi daripada kesiapan menikah perempuan. Namun 
nilai rata-rata tertinggi berada pada aspek kesiapan pribadi dan nilai rata-rata terendah berada pada aspek kesiapan situasi. Sebelum menikah, baik laki-laki maupun perempuan harus mempersiapkan beberapa hal yang akan menjadi bekal dalam pernikahannya yang kelak. Tidak hanya persiapan ritual, namun yang utama adalah pemahaman tentang hakikat pernikahan dalam kehidupan beragama dan bermasyarakat. Karena pernikahan bukan hanya hidup berdua, namun juga hidup bermasyarakat.

Dari hasil penelitian juga mengungkapkan bahwa rata-rata kesiapan menikah mahasiswa BK FIP UNP berada pada kategori sedang (S). Hal ini dikarenakan mahasiswa BK FIP UNP berada pada usia dewasa awal yang ditandai dengan tugas perkembangan untuk menikah, keberhasilan pencapaian tugas perkembangan diharapkan dapat melahirkan kebahagian dan kesuksesan bagi individu untuk menyelesaikan tugas-tugas berikutnya. Sebaliknya kegagalan dan seterusnya.Dari temuan ini kiranya mendukung penelitian dari Fatimah (2010) mengungkapkan bahwa hampir setiap pemuda (laki-laki dan perempuan) mempunyai dua tujuan utama, pertama menemukan jenis pekerjaan yang sesuai; kedua menikah dan membangun rumah tangga (keluarga). Banyak faktor yang mempengaruhi seseorang mencapai kedua tujuan tersebut.

Berdasarkan hasil temuan penelitian juga dapat disimpulkan bahwa kombinasi dari variabel jenis kelamin, latar belakang budaya dan kondisi sosial ekonomi serta kombinasi variabel jenis kelamin, latar belakang budaya dan kondisi sosial ekonomi menunjukkan interaksi yang tidak signifikan dalam menjelaskan kesiapan menikah mahasiswa. Dengan hasil analisis tersebut memberikan simpulan bahwa semua kombinasi antara variabel jenis kelamin, latar belakang budaya dan kondisi sosial ekonomi tidak memiliki interaksi.Hasil penelitian juga mempertegas bahwa beberapa faktor yang tidak dapat memberikan pengaruh terhadap kesiapan menikah mahasiswa, diantaranya adalah jenis kelamin, latar belakang budaya dan kondisi sosial ekonomi mahasiswa BK FIP UNP. Selanjutnya, dari hasil uji hipotesis, kiranya dapat menjadi rujukan bagi konselor untuk melaksanakan pelayanan dalam BK di perguruan tinggi. Hasil Penelitian Desneli, Firman \& Sano (2016) menujukkan layanan informasi efektif untuk meningkatkan penyesuaian diri siswa. Kesiapan menikah sangat diperlukan dalam penyesuaian diri dalam pernikahan. Pemberian layanan informasi juga efektif dalam meningkatkan kesiapan menikah mahasiswa sehingga nantinya mahasiswa dapat menyesuaikan diri dengan lingkungannya.

\section{KESIMPULAN}

Berdasarkan hasil temuan yang diperoleh dalam penelitian ini, dimana telah dilakukan analisis statistik dan uji hipotesis serta dikaji dan dijabarkan dalam pembahasan, maka dapat disimpulkan bahwa:Secara umum tingkat kesiapan menikah mahasiswa ditinjau dari jenis kelamin laki-laki dan perempuan berada pada kategori sedang dan tidak terdapat perbedaan yang signifikan antara mahasiswa laki-laki dan perempuan dalam menjelaskan kesiapann menikah.Secara umum tingkat kesiapan menikah mahasiswa budaya Patriarkhat dan Matriarkhat berada pada kategori sedang; tidak terdapat perbedaan yang signifikan antara mahasiswa budaya Patriarkhat dan Matriarkhat dalam menjelaskan kesiapan menikah mahasiswa.Secara umum tingkat kesiapan menikah mahasiswa dilihat dari kondisi sosial ekonomi pekerjaan orangtua tetap dan pekerjaan orangtua tidak tetap berada pada kategori sedang dan tidak terdapat perbedaan yang signifikan antara mahasiswa yang pekerjaan orangtuanya tetap dan pekerjaan orangtuanya tidak tetap dalam menjelaskan kesiapan menikah.Secara umum tidak terdapat interaksi antara variabel jenis kelamin, latar belakang budaya dan kondisi sosial ekonomi dalam menjelaskan kesiapan menikah.Berdasarkan hipotesis dalam penelitian ini menegaskan bahwa bimbingan dan konseling pernikahan di perguruan tinggi dibutuhkan dalam upaya mempertahan serta meningkatkan kesiapan menikah mahasiswa. Selanjutnya, dalam pelaksanaan pelayanan bimbingan dan konseling pernikahan di perguruan tinggi diharapkan untuk mempertimbangkan akan perbedaan jenis kelamin, latar belakang budaya dan kondisi sosial ekonomi dalam menentukan prioritas sasaran layanan.

\section{DAFTAR RUJUKAN}

Afdal. (2015). Pemanfaatan Konseling Keluarga Eksperensial untuk Penyelesaian Kasus Kekerasan dalam Rumah Tangga. Jurnal Education. (Vol.1, No.1), 76-79, ISSN: 24770302.

Blood, R. O. (1987). Marriage. $2^{\text {nd }}$ ed. New York.

Cashion. (1983). Sociology an Introduction. USA: Little Brown \& Co (T).

Desneli, Firman, Sano, A. (2016). Peningkatan Penyesuaian Diri Siswa Melalui Layanan Informasi. Jurnal Education. (Vol.2, No. 2), 8-13, ISSN: 2477-0302.

Duvall dan Miller.(1985). Marriage and Family Development. Newyork: Harper \& Row. Fatimah, E. (2010). Psikologi Perkembangan. Bandung: Pustaka Setia. 
Fatimah, S. \& Wirdanengsih. (2016). Gender dan Pendidikan Multikultural. Jakarta: Kencana. Gladding, S. T. (2012). Konseling (Profesi yang Menyeluruh). Jakarta: Index.

, P. Y. \& Syahniar. (2014). Tingkat Hubungan Sosial Ditinjau dari jenis Kelamin, Latar Belakang Budaya dan Implikasi dalam Bimbingan dan Konseling. Jurnal Konselor. (Volume 3, No.3), ISSN: 1412-9760.

Hurlock, E. B. (2012). Developmental Psychology, A Life-Span Approach, Fifth Edition. Alih Bahasa Isti Widayanti dan Soedjarwo. Jakarta: Erlangga.

Kartono, K. (1992). Psikologi Wanita (Jilid 2). Bandung: Mandar Maju.

Kamanto, S. (2011). Pengantar Sosiologi. Jakarta: Lembaga Penelitian FE-UI.

Kenedi, G. (2005). Model Konseling Pranikah Berorientasi Pengembangan Konsep Diri. Disertasi tidak diterbitkan. Bandung: Program Pascasarjana UPI Bandung.

Koentjaraningrat. (2009). Pengantar Ilmu Antropologi. Jakarta: Rineka Cipta.

Krisnatuti, D. \& Oktaviani, V. (2010). Persepsi dan Kesiapan Menikah pada Mahasiswa. Jurnal Ilmu Keluaga dan Konsumen. (Vol. 4, No. 1), 30-36, ISSN: 1907-6037.

Marjohan. (2013). Pengembangan Internal Locus of Control dalam Pelayanan Konseling dan Implikasinya terhadap Perbedaan Budaya Klien. Jurnal Konseling dan Pendidikan. (Vol.1,No.2), 136-142, ISSN: 2337-6880.

Nirwana, H.(2003). Hubungan Tingkat Aspirasi dan Persepsi tentang Belajar dengan Hasil Belajar Matematika Siswa SMU yang Berlatar Belakang Budaya Minangkabau dan Batak”. Disertasi Tidak Diterbitkan. Malang: Program Studi Psikologi Pendidikan.

Oktaviani, N. (2014). Faktor Penyebab Orang Dewasa Awal Menunda Pernikahan. Jurnal.Padang: BK STKIP SUMBAR

Papalia, D. E. (2014). Experience Human Development. McGraw: Hill Education.

Prayitno, E. (2006). Psikologi Perkembangan Dewasa. Padang: Angkasa Raya.

Prayitno. (2012). Jenis layanan dan kegiatan pendukung konseling. Padang: PPK BK FIP UNP.

Purwanto, N. (2009). Ilmu Pendidikan ( Teoritis dan Praktis). Bandung: Remaja Rosda Karya.

Sahara, S. dkk. (2012). Model Paket Layanan Penguasaan Konten Bertema Kesiapan Menikah BerbasisMultimedia pada Mahasiswa. Indonesian Journal of Guidance and Counseling: Theory and Application. (Vol. 1, No.1), ISSN: 2252-6374.

Santrock. (2007). Adolescene: Perkembangan Masa Remaja (diterjemahkan oleh Achmad Chusairi \& Juda Damanik). Jakarta: Erlangga.

Sari, F. \& Sunarti, E. (2013). Kesiapan Menikah pada Dewasa Muda dan Pengaruhnya terhadap Usia Menikah. Jurnal Ilmiah Keluarga \& Konseling. (Vol. 6, No. 3), 143-153, ISSN: 19076037.

Silalahi, K \& Meinarno, E. (2010). Keluarga Indonesia: Aspek dan Dinamika Zaman. Jakarta:Rajawali Pers.

Soekanto, S.(2013) . Sosiologi Suatu Pengantar . Jakarta : Raja Grafindo Persada.

Sugandi, N. M. (2010). Model Bimbingan dan Konseling Perkembangan untuk Meningkatkan Kesiapan Menikah Mahasiswa. Disertasi tidak Diterbitkan. Bandung: Program Pascasarjana UPI Bandung.

Tsania, N., Sunarti, E. \& Krisnatuti, D.. (2015). Karakteristik Keluarga, Kesiapan Menikah Istri, dan Perkembangan Anak Usia 3-5 Tahun. Jurnal Ilmu Keluarga dan Konsumen. (Vol.8, No. 1), 28-37, ISSN:1907-6037.

Undang-Undang Republik Indonesia Nomor 1 Tahun 1974 tentang Perkawinan.

Walgito, B. (2010). Bimbingan dan Konseling Perkawinan. Yogyakarta: Andi.

Willis, S. S. (2013). Konseling Keluarga. Bandung: Alfabeta.

Wirdana, I., dkk. (2013). Kurikulum Diklat Teknis Bina Keluarga Remaja Bagi Kader Bina Keluarga Remaja. Jakarta: Badan Kependudukan dan Keluarga Berencana Nasional.

Wisnuwardhani, D. \& Mashoedi, S. F. (2012). Hubungan Interpersonal. Jakarta: SalembaHumanika.

Yahya, Y. (2012). Psikologi Perkembangan. Jakarta: Kencana.

Yendi, F. M., Ardi, Z., \& Ifdil. (2014). Counseling Service for Women in Marriage Age. Jurnal Konseling dan Pendidikan. (Vol. 2, No. 3), 31-36, ISSN:2337-6880.

Yusuf L. N., Syamsu \& Sugandhi, N.M. (2012). Perkembangan Peserta Didik: Mata Kuliah Dasar Profesi (MKDP) Bagi Para Mahasiswa Calon Guru di Lembaga Pendidikan Tenaga Pendidikan. Jakarta: Rajawali Pers. 